\title{
The prevalence of complementary and alternative methods and their impact on conventional cancer treatment among oncological patients in Poland - an institutional study
}

\author{
Rozpowszechnienie metod medycyny komplementarnej i alternatywnej \\ oraz ich wpływ na konwencjonalne leczenie przeciwnowotworowe \\ wśród pacjentów onkologicznych w Polsce - badanie jednoośrodkowe
}

\author{
Konrad Reszka1, Łukasz Moskal', Agata Remiorz ${ }^{1}$, Agata Walas¹, Mateusz Guzik¹, Natalia Kierbiedź \\ Krzysztof Szewczyk ${ }^{1,2}$, Urszula Staszek-Szewczyk $k^{1,3,4}$
}

'Department of Oncology, Wroclaw Medical University, Wroclaw, Poland Head of the Department: Prof. Rafał Matkowski MD, PhD

2Department of Oncology, Division of Surgical Oncology, Wroclaw Medical University, Wroclaw, Poland Head of the Department: Prof. Rafał Matkowski MD, PhD

${ }^{3} 1^{\text {st }}$ Department of Surgical Oncology, Wroclaw Regional Comprehensive Cancer Centre, Wroclaw, Poland Head of the Department: Prof. Rafał Matkowski MD, PhD

${ }^{4}$ Department of Brachytherapy, Wroclaw Regional Comprehensive Cancer Centre, Wroclaw, Poland

Head of the Department: Adam Maciejczyk MD, PhD

Key words: complementary and alternative medicine, oncological patients, Polish health care system.

Słowa kluczowe: medycyna komplementarna i alternatywna, pacjenci onkologiczni, polski system opieki zdrowotnej.

\begin{abstract}
Introduction: Nowadays, complementary and alternative medicine (CAM) is gaining more adherents in Poland. Awareness of CAM methods among medical professionals is unsatisfactory. The gap that has been created in the Polish health care system opens the field for abuse. Poor knowledge about the popularity of CAM therapies among oncological patients in Poland led us to the evaluation of their prevalence and features.

Aim of the research: To assess the prevalence of CAM procedures and their impact on conventional cancer treatment in Poland. Material and methods: A cross-sectional study was conducted in the Lower Silesian Oncology Centre, Poland. The final research group came to 355 respondents ( 209 women, $146 \mathrm{men}$, response rate $58 \%$ ). Inclusion criteria comprised the following: diagnosed cancer, staged from early to advanced, and ongoing conventional treatment. Exclusion criteria were as follows: incomplete diagnostic path for cancer, age below 18 years, and complete remission of the disease.

Results: CAM methods were used by 156 (43.9\%) patients. The most popular were herbal drugs (50.6\%), linseed (49.4\%), and apricot seeds (32.7\%). Approximately $40 \%$ of patients informed their doctor about CAM usage. More than $7 \%$ had resigned from standard treatment in the past. Almost $2 \%$ of respondents considered suspending therapy in the future. Factors associated with CAM use were as follows: female gender ( $51.2 \%$ vs. $33.56 \% ; p<0.05)$, secondary and higher education $(47.1 \%$ secondary, $51.8 \%$ higher vs. $19.2 \%$ primary, $38.46 \%$ vocational; $p<0.05)$, education associated with health care $(68.4 \%$ vs. $41.0 \% ; p<0.05)$. Conclusions: CAM techniques are popular among oncological patients in Poland and are often used on their own. No single factor affecting CAM use was established. Besides oncological treatment, patients should be informed about the effectiveness and the side-effects of CAM and the dangers associated with standard treatment refusal.
\end{abstract}

\section{Streszczenie}

Wprowadzenie: Metody tzw. medycyny komplementarnej i alternatywnej (CAM) zyskują w Polsce na popularności. Wiedza pracowników ochrony zdrowia na ich temat jest niezadowalająca. Powstała w ten sposób luka w polskim systemie opieki zdrowotnej stwarza pole do nadużyć. Niedostateczna wiedza na temat rozpowszechnienia terapii CAM wśród pacjentów onkologicznych w Polsce skłoniła nas do oceny ich popularności i cech charakterystycznych.

Cel pracy: Ocena popularności technik CAM oraz ich wpływu na konwencjonalne leczenie onkologiczne w Polsce.

Materiał i metody: Badanie przekrojowe przeprowadzono w Dolnośląskim Centrum Onkologii. Ostateczna grupa badana liczyła 355 osób (209 kobiet, 146 mężczyzn, odsetek odpowiedzi 58\%). Kryteria włączenia obejmowały: rozpoznany nowotwór, stadium od wczesnego do zaawansowanego, trwające leczenie onkologiczne. Kryteriami wykluczenia były: niepełna ścieżka diagnostyczna nowotworu, wiek poniżej 18 lat, całkowita remisja choroby. 
Wyniki: Metody CAM były stosowane przez 156 (43,9\%) pacjentów. Najpopularniejsze były: leki ziołowe (50,6\%), siemię Iniane (49,4\%), pestki moreli (32,7\%). Około 40\% pacjentów poinformowało swojego lekarza o stosowanych technikach CAM. Ponad 7\% ankietowanych przyznało się do rezygnacji z konwencjonalnego leczenia w przeszłości, prawie $2 \%$ rozważało rezygnację w przyszłości. Czynnikami związanymi z częstszym użyciem CAM były: płeć żeńska (51,2\% vs 33,56\%; $p<0,05)$, wykształcenie średnie i wyższe (47,1\% średnie, $51,8 \%$ wyższe $v s$ 19,2\% podstawowe, 38,46\% zawodowe; $p<0,05)$, wykształcenie medyczne $(68,4 \%$ vs $41,0 \% ; p<0,05)$.

Wnioski: Metody CAM są popularne wśród pacjentów onkologicznych w Polsce, którzy często wykorzystują je na własną rękę. Nie stwierdzono konkretnego czynnika predylekcyjnego związanego z CAM. Pacjenci powinni być informowani o efektach i działaniach ubocznych CAM i leczenia onkologicznego oraz o zagrożeniach związanych z rezygnacją z konwencjonalnej terapii.

\section{Introduction}

Cancer is the second leading cause of death in Poland, accounting for $26.3 \%$ of deaths among men and $23.1 \%$ among women in 2017 [1]. The number of patients diagnosed with malignant tumours has doubled in the last 3 decades [2]. The Polish Cancer Society (PTO) anticipates an over 15\% increase in the incidence of cancer in our country by 2027, as compared with 2017 [3]. Despite the improvement in treatment results and introduction of new cancer drugs, reports show that cancer patients in Poland have more restricted access to innovative cancer drugs than patients in other European Union countries [4].

Disparities in access to treatment concern conventional oncological therapies defined as an evidencebased medicine (EBM) - systemic treatment, radiotherapy, and surgery in proper, approved schemes. As a result, complementary and alternative methods of dealing, represented by techniques used along with standard medical treatment or instead of conventional therapy gain more and more adherents, which follow along trends promoted widely by social and massmedia [5-7]. However, there are no reliable sources of knowledge about complementary and alternative medicine (CAM) in Poland. The growing popularity of these methods has promoted many charismatic authors, the majority of whom are without any medical qualifications, who started publishing books and treatment programs based on their beliefs and philosophies regarding health and diseases [8].

While there is a guild craft of therapists, approved by law, practicing so-called natural medicine, acupuncture, and chiropractic procedures in Poland, there are no legal provisions on using CAM methods in the Polish health care system [9]. Moreover, activities of specialists gathered in this community are not subject to the control of any health organisation, and their legal liability is not sufficiently regulated [10]. Awareness of Polish medical students regarding CAM and self-medication is also unsatisfactory and they are frequently not familiar with the scale of the phenomenon [11, 12]. Moreover, the lack of patient-physician communication in medical curricula exacerbate the presented problem.

Unfortunately, there is limited number of studies concerning use of complementary and alternative methods among Polish patients; therefore, it is difficult to evaluate the popularity of these practices, especially among people diagnosed with cancer [13]. Nevertheless, oncological patients may be prone to trust charlatans and information of unknown origin promising them a long, healthy life. This serious gap in the Polish health care system opens a field for abuse.

A number of CAM techniques are based on traditional methods of treatment and substances found in the natural environment [14]. Undoubtedly, some complementary therapies can improve quality of life [15]. However, misapplied CAM methods may be dangerous for health or even patients' lives. Because of numerous interactions between complementary and conventional treatment, administered therapies should always be preceded by a physician consultation [16]. Furthermore, it was proven that patients who used complementary medicine had higher risk of death due to greater probability of additional conventional cancer treatment denial [17].

\section{Aim of the research}

The knowledge gap regarding the popularity of CAM therapies among oncological patients in Poland led to an evaluation of its prevalence with identification of the procedures used most frequently. We investigated socio-demographic factors associated with the use of CAM, as well as the association between the use of CAM methods and the reliance on physicians, opinions on the severity of the disease, and the effectiveness of the therapy. We also defined sources of knowledge about conventional and unconventional treatment. Finally, our manuscript is a response to the challenges in medicine of the $21^{\text {st }}$ century, including the constantly increasing expectations of oncological patients, the desire for direct self-autonomy, and their lack of trust in the patient-physician relationship.

\section{Material and methods}

\section{Materials}

The study was conducted in the Lower Silesian Oncology Centre from December 2017 to January 2019. The inclusion criteria for patients consisted of the following: diagnosed malignant neoplasm of any inter- 
nal organ, stage of the disease from early to advanced, and ongoing conventional treatment. Exclusion criteria included the following: incomplete diagnostic path for cancer, age below 18 years, and complete remission of the disease. In total 614 patients were invited to take part in the research. Of those, 259 denied or returned the survey filled out incorrectly. Eventually, the research group included 355 responders - 209 women and 146 men.

The study group consisted of 355 responders: 209 women and 146 men. The mean age of respondents was $60 \pm 13$ years. Most of them were married
(251;70.7\%) or declared themselves to be a widow/ widower $(56 ; 15.8 \%)$, and most had offspring (312; $87.9 \%$ vs. $43 ; 12.1 \%)$. Most of the people lived in metropolitan (93; 26.2\%) and rural areas (102; 28.7\%). Secondary education was declared most frequently (155; 43.7\%), while $38(10.7 \%)$ confirmed education associated with health care. Most participants had religious beliefs, practicing once a week (160; 45.1\%). In the majority of cases, oncological disease lasted for a few months $(156 ; 44 \%)$. Respondents were treated with surgery (276; 77.7\%), chemotherapy (126; 35.5\%), and radiotherapy $(73 ; 20.6 \%)$ (Table 1$)$.

Table 1. Characteristics of the study group

\begin{tabular}{|c|c|c|c|c|}
\hline Variable & & Non-CAM users & CAM users & Total \\
\hline Age [years] median \pm SD & & $60 \pm 13$ & & \\
\hline \multirow[t]{2}{*}{ Gender } & Male & 97 (27.30\%) & $49(13.80 \%)$ & $146(41.10 \%)$ \\
\hline & Female & $102(28.70 \%)$ & 107 (30.10\%) & 209 (58.90\%) \\
\hline \multirow[t]{5}{*}{ Marital status } & Married & $148(41.70 \%)$ & $103(29.00 \%)$ & $251(70.70 \%)$ \\
\hline & Single & $10(2.80 \%)$ & $14(3.90 \%)$ & $24(6.80 \%)$ \\
\hline & Widow(er) & $30(8.50 \%)$ & $26(7.30 \%)$ & $56(15.80 \%)$ \\
\hline & Open relationship & $1(0.30 \%)$ & $3(0.90 \%)$ & $4(1.10 \%)$ \\
\hline & Informal relationship & $10(2.80 \%)$ & $10(2.80 \%)$ & $20(5.60 \%)$ \\
\hline Having offspring & & $178(50.10 \%)$ & $134(37.80 \%)$ & $312(87.90 \%)$ \\
\hline \multirow{5}{*}{$\begin{array}{l}\text { Place of living - } \\
\text { no. of citizens }\end{array}$} & City $>500,000$ & $48(13.50 \%)$ & $45(12.70 \%)$ & $93(26.20 \%)$ \\
\hline & City $<500,000$ & $11(3.10 \%)$ & $10(2.80 \%)$ & $21(5.60 \%)$ \\
\hline & City $<100,000$ & $52(14.70 \%)$ & $36(10.10 \%)$ & $88(24.80 \%)$ \\
\hline & City $<10,000$ & $31(8.70 \%)$ & $20(5.60 \%)$ & $51(14.70 \%)$ \\
\hline & Village & 57 (16.10\%) & 45 (12.70\%) & $102(28.70 \%)$ \\
\hline \multirow[t]{4}{*}{ Education level } & Primary & $21(5.90 \%)$ & $5(1.40 \%)$ & $26(7.30 \%)$ \\
\hline & Secondary & $82(23.10 \%)$ & $73(20.60 \%)$ & $155(43.70 \%)$ \\
\hline & Professional & $56(15.80 \%)$ & 35 (9.90\%) & $91(25.60 \%)$ \\
\hline & Higher & $40(11.30 \%)$ & $43(12.10 \%)$ & $83(23.40 \%)$ \\
\hline Medical education & & $12(3.40 \%)$ & $26(7.30 \%)$ & $38(10.70 \%)$ \\
\hline \multirow{5}{*}{$\begin{array}{l}\text { Participation in } \\
\text { religious practices }\end{array}$} & Atheist & $3(0.80 \%)$ & $16(4.50 \%)$ & 19 (5.30\%) \\
\hline & Non-practising & $22(6.20 \%)$ & 17 (4.80\%) & 39 (11.00\%) \\
\hline & Occasional & 44 (12.40\%) & $62(17.50 \%)$ & $106(29.90 \%)$ \\
\hline & Once a week & 69 (19.40\%) & 91 (25.60\%) & $160(45.10 \%)$ \\
\hline & Every day & 18 (5.10\%) & $13(3.70 \%)$ & 31 (8.70\%) \\
\hline \multirow{6}{*}{$\begin{array}{l}\text { Duration of oncological } \\
\text { treatment }\end{array}$} & Few months & 89 (25.10\%) & 67 (18.90\%) & $156(44.00 \%)$ \\
\hline & 1 year & 24 (6.80\%) & 35 (9.90\%) & 59 (16.60\%) \\
\hline & $2-3$ years & 30 (8.50\%) & 29 (8.20\%) & 59 (16.60\%) \\
\hline & $4-5$ years & 13 (3.70\%) & 13 (3.70\%) & 26 (7.30\%) \\
\hline & $6-9$ years & $13(3.70 \%)$ & 11 (3.10\%) & 24 (6.80\%) \\
\hline & $10+$ years & $12(3.40 \%)$ & 19 (5.40\%) & 31 (8.70\%) \\
\hline
\end{tabular}




\section{Variables}

The research was based on the authors' questionnaire comprising open-ended, closed-ended, and nominal, multiple-choice questions with predefined answers as well as rating scales from 1 to 10 . For nominal questions an additional, optional space was provided for respondents to implement answers not included by the authors. The survey was divided into 3 parts concerning the following: socio-demographic data, information about current therapy, and usage of CAM practices. In the first part, patients were asked about their marital status (married, single, widow/ widower, open relationship, informal relationship), having offspring, place of residence (metropolitan and non-metropolitan areas, countryside), education level (primary, secondary, professional, higher, medical or non-medical), and participation in religious practises (atheist, non-practising, practising occasionally, practising once a week, or practising every day).

The second part contained questions about the duration of oncological treatment (a few months, about 1 year, 2-3 years, 4-5 years, 6-9 years, 10 or more years) and conventional methods used so far (surgery, chemotherapy, radiotherapy). It also contained questions concerning patients' awareness or unawareness of potential side effects and sources of knowledge about conventional treatment. Respondents were asked to subjectively evaluate the severity of their disease, their trust toward the attending physician, the effectiveness of current therapy, and treatment inconvenience (on a scale of 1 to 10 ).

Last part consisted of questions considering CAM methods used currently and in the past. While the predefined list of CAM modalities was based on the literature review and personal experience, respondents also had an opportunity to give answers not included by the authors. Patients were asked about the frequency of these procedures, sources of knowledge about CAM, the effectiveness of these therapies in their own opinion, and the attending physician's awareness of the CAM techniques used by their patients. Participants were also asked if they would be able to terminate complementary or alternative treatment if their doctor insisted on it, and if they have ever given up on the possibility of standard treatment in favour of unconventional treatment. Inquiries concerning their sense of improvement after CAM administration and the potential harmfulness of these practices were included at the end of the questionnaire.

\section{Statistical analysis}

In the statistical analysis, the $\chi^{2}$ independence test was used to assess the relationship between the studied variables in the nominal and ordinal scales. ShapiroWilk test was used to assess the normality of variable distribution. The Mann-Whitney test was used to assess the difference between the 2 groups. Statistical analysis was performed using Statistica v.12.5 (StatSoft).

\section{Results}

\section{History of usage of CAM methods}

Among the respondents, 156 (43.9\%) confirmed using CAM methods. The most popular were herbal drugs (79; 50.6\%), linseed (77; 49.4\%), apricot seeds (51; $32.7 \%$ ), intravenous vitamin $\mathrm{C}$ infusion (34; 21.8\%), megadoses of vitamins $(27 ; 17.3 \%)$, vitamin $\mathrm{B}_{17}(24$; $15.4 \%)$, holy water (15; 9.6\%), healing minerals (14; 9\%), prayerful groups $(11 ; 7.1 \%)$, and acupuncture and acupressure $(11 ; 7.1 \%)$. Only $15.4 \%$ of respondents thought that these methods could be unsafe, $48.7 \%$ responded it is completely safe, and $35.9 \%$ did not know. Moreover, only $39.7 \%$ of the CAM users informed their doctor about alternative treatment they had undergone.

Fifty-nine percent of the patients claimed they were feeling better after the administration of unconventional techniques. Almost $40 \%$ of the patients responded that, in their opinion, CAM is less effective than conventional treatment, $35.9 \%$ that it is equally effective, and $1.9 \%$ that it is more effective than conventional therapy.

Most of the CAM-users never refused conventional treatment in favour of CAM therapies (71.2\%) and considered it as a supplement. However, 16.7\% believed that CAM is crucial to achieve remission, while $9 \%$ respondents put off visits in a clinic, omitted part of their therapy, or gave up on medicines recommended by their attending physician. More than $7 \%$ admitted that in the past, for some period of time, they completely resigned from standard treatment recommended by doctors. Almost $2 \%$ of respondents considered suspending their therapies in the future. Only about $30 \%$ of participants were able to give up alternative treatment if their doctor insisted on it.

Knowledge about CAM methods was obtained at the first place from family and friends (73; 46.8\%), followed by the Internet $(67 ; 43 \%)$, books $(65 ; 41.7 \%)$, TV, radio, and press $(28 ; 17.9 \%)$, a physician $(36 ; 23.1 \%)$, and other medical staff $(21 ; 13.5 \%)$. On the other hand, the most common sources of information about conventional care were physicians $(123 ; 78.8 \%)$, the Internet $(75 ; 48.1 \%)$, other patients $(55 ; 35.3 \%)$, family and friends $(51 ; 32.7 \%)$, TV, radio, and press (43; $27.6 \%)$, and other medical staff $(19 ; 12.2 \%)$.

\section{Factors associated with usage} of complementary and alternative methods

The majority of patients in CAM using group were women (51.2\% females vs. 33.56\% males; $p<0.05)$, with secondary and higher education (47.1\% secondary, $51.8 \%$ higher vs. $19.2 \%$ primary, $38.46 \%$ vocational; $p<0.05)$, education associated with health care (68.4\% yes vs. $41.0 \%$ no; $p<0.05)$, believers practicing 
once a week and non-practicing $(58.1 \%$ practicing believers (more than once per week), 56.4\% non-practicing believers vs. $43.1 \%$ practicing believers (once per week), $41.5 \%$ practicing believers (a few times per year) vs. $15.8 \%$ non-believers; $p<0.05$ ). There were no statistically significant differences between groups using and not using CAM in relation to marital status and presence of offspring, place of residence, reliance toward the attending physician, subjective evaluation of severity of the disease, and the effectiveness of oncological treatment.

\section{Factors associated with the selection of CAM methods}

Considering particular unconventional methods, we have indicated factors related with their usage. Patients in the group using linseed were more likely to be female $(28.2 \%$ females vs. $12.3 \%$ males; $p<0.001)$, with secondary education (28.4\% secondary vs. $7.7 \%$ primary, $16.5 \%$ vocational, $19.3 \%$ higher; $p<0.05$ ).

Patients using herbal drugs were significantly younger than non-users $(p<0.01)$, and they were more likely to be female $(29.2 \%$ females vs. $12.3 \%$ males, $p<0.001$ ), with secondary and higher education (28.4\% secondary, $24.1 \%$ higher vs. $3.8 \%$ primary, $15.4 \%$ vocational; $p<0.05$ ) (Table 2 ).

Patients using apricot seeds were significantly younger than patients not using apricot seeds $(p<0.001)$, and they rated their health significantly differently (19.8\% "I feel slightly worse than before", $18.7 \%$ "I feel very sick" vs. $6.5 \%$ "I feel healthy", 10.6\% "I feel much worse than before"; $p<0.05)$. They were also aware of potential side effects of conventional oncological treatment (18.2\% being aware vs. $9.2 \%$ not being aware; $p<0.05)$.

Table 2. Factors associated with herbal drugs selection

\begin{tabular}{|c|c|c|c|c|}
\hline Parameter & & Herbal drugs & Herbal drugs & $P$-value \\
\hline \multirow[t]{2}{*}{ Gender } & Male & $18(12.33 \%)$ & $128(87.67 \%)$ & \multirow[t]{2}{*}{0.00017} \\
\hline & Female & 61 (29.19\%) & 148 (70.81\%) & \\
\hline \multirow[t]{5}{*}{ Marital status } & Married & $54(21.51 \%)$ & 197 (78.49\%) & \multirow[t]{5}{*}{0.81044} \\
\hline & Single & $7(29.17 \%)$ & 17 (70.83\%) & \\
\hline & Widow(er) & 11 (19.64\%) & 45 (80.36\%) & \\
\hline & Open relationship & $1(25.00 \%)$ & $3(75.00 \%)$ & \\
\hline & Informal relationship & $6(30.00 \%)$ & 14 (70.00\%) & \\
\hline \multirow[t]{2}{*}{ Having offspring } & Yes & 67 (21.47\%) & 245 (78.53\%) & \multirow[t]{2}{*}{0.34175} \\
\hline & No & 12 (27.91\%) & 31 (72.09\%) & \\
\hline \multirow{5}{*}{$\begin{array}{l}\text { Place of living - } \\
\text { no. of citizens }\end{array}$} & City $>500,000$ & $20(21.51 \%)$ & $73(78.49 \%)$ & \multirow[t]{5}{*}{0.50843} \\
\hline & City $<500,000$ & $6(28.57 \%)$ & $15(71.43 \%)$ & \\
\hline & City $<100,000$ & $21(23.86 \%)$ & 67 (76.14\%) & \\
\hline & City $<10,000$ & 7 (13.73\%) & $44(86.27 \%)$ & \\
\hline & Village & 25 (24.51\%) & 77 (75.49\%) & \\
\hline \multirow[t]{4}{*}{ Education level } & Primary & $1(3.85 \%)$ & 25 (96.15\%) & \multirow[t]{4}{*}{0.00431} \\
\hline & Secondary & 44 (28.39\%) & $111(71.61 \%)$ & \\
\hline & Professional & $14(15.38 \%)$ & 77 (84.62\%) & \\
\hline & Higher & 20 (24.10\%) & $63(75.90 \%)$ & \\
\hline \multirow[t]{2}{*}{ Medical education } & Yes & $13(34.21 \%)$ & 25 (65.79\%) & \multirow[t]{2}{*}{0.07303} \\
\hline & No & 66 (20.82\%) & 251 (79.18\%) & \\
\hline \multirow{5}{*}{$\begin{array}{l}\text { Participation in } \\
\text { religious practices }\end{array}$} & Atheist & $3(15.79 \%)$ & $16(84.21 \%)$ & \multirow[t]{5}{*}{0.52968} \\
\hline & Non-practising & $12(30.77 \%)$ & 27 (69.23\%) & \\
\hline & Occasional & $22(20.75 \%)$ & $84(79.25 \%)$ & \\
\hline & Once a week & 33 (20.63\%) & 127 (79.38\%) & \\
\hline & Every day & 9 (29.03\%) & 22 (70.97\%) & \\
\hline
\end{tabular}


Patients using vitamin C infusions were more likely to live in villages and in cities with more than 100,000 inhabitants (19.1\% city with less than 500,000 inhabitants, $12.9 \%$ city with more than 500,000 inhabitants, $11.8 \%$ village vs. $7.8 \%$ city with up to 10,000 inhabitants, $2.3 \%$ city with up to 100,000 inhabitants; $p<0.05)$, while patients using megadoses of vitamins were younger $(p<0.01)$ and more likely to be female (10.1\% females vs. $4.1 \%$ males; $p<0.05)$, living in a village or city with more than 100,000 inhabitants (11.7\% village, $9.5 \%$ city with less than 500,000 inhabitants, $8.6 \%$ city with more than 500,000 inhabitants, vs. $0.0 \%$ city with up to 10,000 inhabitants, $5.7 \%$ city with up to 100,000 inhabitants; $p<0.05$ ).

\section{Discussion}

Alternative medicine, not only in Poland but also all over the world, is a constantly developing form of treatment and therapy. Eisenberg et al. stated that between 1990 and 1997 the use of CAM increased from $33.8 \%$ to $42 \%$ [18-20]. Differences in its use have been observed, depending on latitude, gender, and, which is especially intriguing, specific communities including medical staff. In highly developed countries, access to modern medicine and innovative therapies is wide, while in developing countries, medicine is based on traditional treatments, which are the only form of medical care in most cases.

Of course, the World Health Organization (WHO) is striving to ensure that everyone has access to stateof-the-art medical technologies, but this is not possible in all regions of the world. The WHO conducts extensive research to verify, at least in a limited way, the safety and effectiveness of traditional treatments $[21,22]$. In general, the quality of evidence for CAM benefits is poor and is frequently provided without sufficient proof from clinical trials [23]. Gender, education, and age are important factors connected with the use of CAM in developed countries. In our research we found that the use of CAM procedures was associated with factors like female gender, higher education, and frequency of religious practices. These results are consistent with prior literature, which also proved that CAM users among oncological patients were more likely to be female, with higher education, and practicing believers [17, 24, 25].

While the number of publications regarding unconventional therapies is increasing, the reliability of many studies is questionable. Nevertheless, oncological patients and their families may be willing to selfadminister these therapies in the hope of recovery. Studies conducted by the WHO Global Atlas of Traditional, Complementary, and Alternative Medicine in 2005 have shown that the most popular methods of CAM are homeopathy, phytotherapy, massage, and herbal therapy. This study did not, however, include methods perceived as religious practices (e.g. prayer, holy water), which are undoubtedly an important group in the presented research.

Most of the respondents in the presented study approve methods of unconventional medicine, which may also be explained by the increased availability, marketing, and relatively low costs of these therapies. The structure of the health care financing system in many countries is not based on the principles of social security, and the costs of medical care are paid by patients from their own pocket [26]. The prices of unconventional medical services are, however, adapted to the financial capacity of each citizen, which makes it affordable for most of the population. Nevertheless, CAM is a multibillion-dollar industry. A national health survey in 2007 revealed that more than \$34 billion is spent on CAM annually in the United States [20]. Unfortunately, similar data for Poland are not available.

Discussion about the place of CAM methods in health care systems is often hampered by the lack of adequate knowledge of doctors regarding the scale of this trend. Ozcakir et al. found a lack of education regarding CAM: $96.5 \%$ of the physicians did not receive such education, while $74.4 \%$ were willing to increase their knowledge in this field. Although knowledge levels were low, about half of physicians (51\%) believed in the efficacy of unconventional therapies [27]. Regrettably, in most countries, there are no reliable courses based on EBM to increase knowledge about these techniques. However, a special position has been acquired by homeopathy. In France, Spain, Germany, as well as in private universities in Austria, Italy, and Belgium, homeopathic items are subject to instruction in medical studies [28]. An interesting fact is that a medical university in Poland started post-graduate studies in 2014 in the field of homeopathy, but it was closed due to numerous protests in 2016 [29]. The introduction of topics regarding selfmedication in medical schools' curricula would enable future physicians to pay more attention to these forms of therapy. What is more, high-quality patientphysician communication cannot be overstated, and this affects the patients' decision to accept or refuse a proposed therapeutic path [30]. Therefore, subjects considering interpersonal skills (e.g. scenarios with professional actors) at medical universities should be implemented. The treatment providers often fail to notice unconventional forms of therapy, and the unasked patient does not address this issue, as presented in our research [31]. In our opinion, this may largely eliminate harmful effects on patient health and improve the effectiveness of treatment.

Presented study shows that oncological patients who used CAM were more likely to have education associated with health care. We did not, however, find an association between the prevalence of CAM usage and patients' subjective evaluation of severity 
of the disease and effectiveness of oncological treatment. A prior literature evaluation demonstrated that patients with higher stages of cancer tended to choose CAM more frequently, but in these studies the severity of the disease was assessed on the basis of medical documentation, not on the basis of the patients self-assessment [17, 32]. Our finding can suggest that the decision about use of unconventional methods was not connected with the patient's malaise. What is more, use of CAM therapies was also not correlated with the reliance on the attending physician and duration of oncological treatment.

The problem of cancer affects not only patients but also their families and friends [4]. Our research demonstrated that patients' relatives also play a major role in the acquisition of knowledge about CAM. The Internet is an important source of knowledge about both conventional and unconventional treatment, while books can provide patients with information about CAM rather than standard oncological treatment. Unfortunately, physicians are one of the less popular sources of knowledge about CAM. To make matters worse, the majority of CAM users did not inform their attending physician about the therapies used of their own volition. It is especially important because of potential dangers related to the use of selfmedication. Moreover, even if the patient would like to inform the physician about plans related to the use of complementary methods, medical professionals frequently do not have the proper training or skills to undertake a discussion and dispel the patient's doubts. Furthermore, the admission questionnaire in the Lower Silesian Oncology Centre, where the study was conducted, does not contain inquiries about unconventional treatment or self-medication used by the patient.

The presented study shows that a significant number of patients using unconventional practices gave up on standard procedures of oncological treatment, while some patients were considering giving up this treatment in the future. It seems to be crucial to apply proper methods of communication with these patients, which should be based on EBM and effective communication skills [33, 34]. The majority of the respondents confirmed improvement after administration of unconventional therapies, which is consistent with prior literature analysis [25].

Our study is limited by its institutional character and small number of participants. Therefore, to precisely evaluate the prevalence of CAM methods among oncological patients in Poland, other oncological centres should be included in further research. The number of CAM-using patients was probably underestimated because of the patients' reluctance to speak about unconventional possibilities of treatment. In future studies, data on refusal should also be collected in order to assess refuser characteristics.
Evaluation of the severity of the disease constitutes another limitation. Because the research was based on the authors' survey, we did not include data from patients' medical documentation in our analyses. Consequently, it was impossible to thoroughly assess the clinical stage of cancer. Previous studies have shown that the type of used CAM may differ by cancer site. However, the survey did not include any question regarding cancer localization. Therefore, CAM use according to cancer site could not be reviewed. Moreover, only patients declaring usage of unconventional procedures were asked if they ever gave up, or they plan to give up, standard methods of treatment. Consequently, we were not able to compare it with a group denying usage of CAM.

Respondents were able to indicate their physician as a source of knowledge about CAM methods, although the physician's opinion on complementary and alternative techniques was not evaluated. As a result, it cannot be determined whether attending doctors encouraged or discouraged their patients from these practices.

The number of denials in our study was relatively high (42.18\%). Because participation was voluntary, patients could decline to take part in the survey without giving any reason. Consequently, we collected no data on refusals. Therefore, it is not possible to determine refuser characteristics and potential differences between respondents and non-respondents. In our opinion, it could be caused by the fear of the physician's reaction or other patients' judgment on CAM techniques. We observe that many patients consider CAM methods as opposition to conventional treatment. Consequently, patients interested in CAM therapies often do not inform the attending physician about self-administered therapies and feel compelled to choose between conventional and unconventional treatment.

\section{Conclusions}

Unconventional techniques are popular among oncological patients in Poland, but are often used on their own and without a physician's recommendation. Polish patients are reluctant to speak about CAM procedures and unasked often do not address this issue. Consequently, health care professionals should pay more attention to CAM methods used by their patients.

While there was no single factor connected with increased probability of using CAM, special attention should be paid to female patients, with higher education level, often associated with health care. However, this data is insufficient to identify a narrow target group of patients. Therefore, all patients should be asked about self-administered CAM therapies.

More than half of CAM users confirmed improvement after administration of unconventional prac- 
tices of unproven safety and effectiveness in cancer treatment. Properly educated physicians should be a reliable source of knowledge for patients regarding the effectiveness and side-effects of CAM and the dangers connected with standard treatment refusal. In our opinion this problem can be solved by providing health care professionals in Poland with training regarding sufficient, high-quality patient-physician communication.

Topics raising students' awareness about CAM and self-medication, as well as proper training in communication skills, should be included in the curricula of medical studies. Legal provisions on using CAM methods in the Polish health care system should be provided and CAM therapists' activities should be subject to the control of proper health care organisations.

\section{Conflict of interest}

The authors declare no conflict of interest.

\section{References}

1. Didkowska J, Wojciechowska U, Czaderny K, Olasek P, Ciuba A. Cancer in Poland in 2017. Krajowy Rejestr Nowotworów, Narodowy Instytut Onkologii im. Marii Skłodowskiej-Curie - Państwowy Instytut Badawczy. Available at http://onkologia.org.pl/wp-content/uploads/Nowotwory_2017.pdf. Accessed 01 November 2020.

2. Wojciechowska U, Didkowska J. Zachorowania i zgony na nowotwory złośliwe w Polsce. Krajowy Rejestr Nowotworów, Narodowy Instytut Onkologii im. Marii SkłodowskiejCurie - Państwowy Instytut Badawczy. Available at http:// onkologia.org.pl/raporty/. Accessed 01 November 2020.

3. Polish Cancer Society (PTO). CANCER CONTROL STRATEGY FOR POLAND 2015-2024. 21 April 2017. Available at https://ligawalkizrakiem.pl/images/content/StrategiaWalki-z-Rakiem-w-Polsce/Strategia_wersja_ang_2017. pdf. Accessed 01 November 2020.

4. Access to innovative cancer drugs in Poland in comparison with selected European Union countries and Switzerland, Report ordered by Young People Oncology Foundation Alivia and prepared by EY Poland, April 2015. Available at https://www.alivia.org.pl/raport2015/05_05_2015_Raport_wersja_EN.pdf. Accessed 01 November 2020.

5. Clarke TC, Black LI, Stussman BJ, Barnes PM, Nahin RL. Trends in the use of complementary health approaches among adults: United States, 2002-2012. Natl Health Stat Report 2015; 79: 1-16.

6. Eisenberg DM, Davis RB, Ettner SL, Appel S, Wilkey S, Van Rompay M, Kessler RC. Trends in alternative medicine use in the United States, 1990-1997: results of a follow-up national survey. JAMA 1998; 280: 1569-1575.

7. Woźniak-Holecka J, Zborowska K, Holecki T. Alternative medicine as a complementary form of treatment in the oncological patients' opinion. Psychoonkologia 2010; 1: 21-28.

8. Woźniak P, Balińska M, Kmieciak Ł. Medycyna komplementarna i alternatywna dziś. Akupunkt Pol 2004; 30: 1150-1169.

9. Wiesener S, Falkenberg T, Hegyi G, Hök J, Roberti di Sarsina P, Fønnebø V. Legal status and regulation of com- plementary and alternative medicine in Europe. Forsch Komplementmed 2012; 19 Suppl 2: 29-36.

10. Piątkowski W. Beyond Medicine. Non-Medical Methods of Treatment in Poland. Peter Lang Frankfurt 2012; 52-63.

11. Wroclaw Medical University, English Division of Medicine Department Curriculum Available at https://www. ed.umed.wroc.pl/sites/default/files/ed/files/curriculum_ EN_2018_2019(1).pdf. Accessed 06 June 2019.

12. Patel SJ, Kemper KJ, Joseph P Kitzmiller JP. Physician perspectives on education, training, and implementation of complementary and alternative medicine. Adv Med Educ Pract 2017; 8: 499-503.

13. Olchowska-Kotala A, Baranski J. Polish physicians' attitudes to complementary and alternative medicine. Complement Ther Med 2016; 27: 51-57.

14. Nobili S, Lippi D, Witort E, Donnini M, Bausi L, Mini E, Capaccioli S. Natural compounds for cancer treatment and prevention. Pharmacol Res 2009; 59: 365-378.

15. Albabtain H, Alwhaibi M, Alburaikan K, Asiri Y. Quality of life and complementary and alternative medicine use among women with breast cancer. Saudi Pharm J 2018; 26: 416-421.

16. Okoronkwo I, Onyia-pat JI, Okpala P, Agbo MA, Ndu A. Patterns of complementary and alternative medicine use, perceived benefits, and adverse effects among adult users in Enugu Urban, Southeast Nigeria. Evid Based Complement Alternat Med 2014; 2014: 239372.

17. Johnson SB, Park HS, Gross CP, Yu JB. Complementary medicine, refusal of conventional cancer therapy, and survival among patients with curable cancers. JAMA Oncol 2018; 4: 1375-1381.

18. Frass M, Strassl RP, Friehs H, Müllner M, Kundi M, Kaye AD. Use and acceptance of complementary and alternative medicine among the general population and medical personnel: a systematic review. Ochsner J 2012; 12: 45-56.

19. Eisenberg DM, Kessler RC, Foster C, Norlock FE, Calkins DR, Delbanco TL. Unconventional medicine in the United States. Prevalence, costs, and patterns of use. N Engl J Med 1993; 328: 246-252.

20. Eisenberg DM, Davis RB, Ettner SL, Appel S, Wilkey S, Van Rompay M, Kessler RC. Trends in alternative medicine use in the United States, 1990-1997: results of a follow-up national survey. JAMA 1998; 280: 1569-1575.

21. WHO. WHO Traditional Medicine Strategy: 2014-2023. World Health Organization, Geneva 2013.

22. WHO. WHO Traditional Medicine Strategy: 2002-2005. World Health Organization, Geneva 2002.

23. Bloom BS, Retbi A, Dahan S, Jonsson E. Evaluation of randomized controlled trials on complementary and alternative medicine. Int J Technol Assess Health Care 2000; 16: 13-21.

24. Richardson MA, Sanders T, Palmer JL, Greisinger A, Singletary SE. Complementary/alternative medicine use in a comprehensive cancer center and the implications for oncology. J Clin Oncol 2000; 18: 2505-2514.

25. Greenlee H, Balneaves LG, Carlson LE, Cohen M, Deng G, Hershman D, Mumber M, Perlmutter J, Seely D, Sen A, Zick SM, Tripathy D, Society for Integrative Oncology. Clinical practice guidelines on the use of integrative therapies as supportive care in patients treated for breast cancer. J Natl Cancer Inst Monogr 2014; 2014: 346-358.

26. McFarland B, Bigelow D, Zani B, Newsom J, Kaplan M. Complementary and alternative medicine use in Canada 
and the United States. Am J Public Health 2002; 92: 1616-

1618 .

27. Ozcakir A, Sadikoglu G, Bayram N, Mazicioglu MM, Bilgel N, Beyhan I. Turkish general practitioners and complementary/alternative medicine. J Altern Complement Med 2007; 13: 1007-1010.

28. Redakcja Homeopatii polskiej. Homeopatia na świecie i w Polsce. Homeopatia Polska. Strona-Forum. Available at https:/homeopatiapolska.com/bazawiedzy/homeopatiana-swiecie-i-w-polsce.html. Accessed 01 November 2020.

29. Redakcja GL. Zlikwidowali studia podyplomowe $z$ homeopatii. Gazeta Lekarska 2016. Available at http://gazetalekarska.pl/?p=28786. Accessed 01 November 2020 .

30. Czerwiński K, Chmielewska M. Alternative therapies in cancer treatment - hope or threat? (qualitative research). Oncol Clin Pract 2021; DOI: 10.5603/OCP.2021.0006.

31. Richardson MA, Mâsse LC, Nanny K, Sanders C. Discrepant views of oncologists and cancer patients on complementary/alternative medicine. Support Care Cancer 2004; 12: 797-804.

32. Akyuz MD, Oran NT, Yucel U, Eksioglu A, Kocak YC. The relationship between hopelessness level and complementary and alternative medicine use in patients with breast cancer. J Cancer Res Ther 2019; 15: 1155-1161.

33. Frenkel M, Cohen L. Effective communication about the use of complementary and integrative medicine in cancer care. J Altern Complement Med 2014; 20: 12-18.

34. Lognos B, Carbonnel F, Boulze Launay I, Bringay S, Guerdoux-Ninot E, Mollevi C, Senesse P, Ninot G. Complementary and alternative medicine in patients with breast cancer: exploratory study of social network forum data. JMIR Cancer 2019; 5: e12536.

\section{Address for correspondence:}

\section{Konrad Reszka MD}

Department of Oncology

Wroclaw Medical University

Wroclaw, Poland

E-mail: reszka.konrad@gmail.com 